\title{
Influence of risk factors on construction firm project success in Pakistan
}

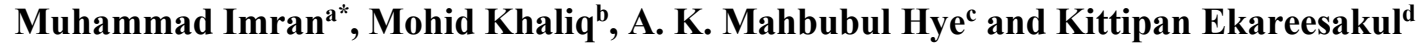

\begin{abstract}
${ }^{a}$ The school of business Management, Universiti Utara Malaysia, Sintok, Kedah, Malaysia
${ }^{b}$ School of Government, College of Law, Government and International studies, Universiti Utara Malaysia, Sintok, Kedah, Malaysia ${ }^{c}$ Department of Electrical \& Electronic Engineering, Prime University, Bangladesh

${ }^{d}$ Department of Public Administration, Prince of Songkhla University, Thailand

\begin{tabular}{l}
\hline C H R O N I C L E \\
\hline Article history: \\
Received October 20, 2018 \\
Received in revised format: \\
October 30, 2018 \\
Accepted December 21, 2018 \\
Available online \\
December 22, 2018 \\
\hline Keywords: \\
Project success \\
Risk assessment \\
Construction
\end{tabular}

A B S T R A C T
The main objective of the present study is to investigate the risk factors influencing on
construction firm's project success in Pakistan. The study uses the partial least square structural
equation modelling technique to analyse the data collected from 61 construction firms. The study
finds positive impacts of design risk, financial risk, technical risk and labour risk on the success
of the project. Alternatively, the current study finds no relationship between external risk factors
and the success of the project. Furthermore, the current study suggests government and
construction firms to consider the risk factors during the decision making for project
implementation.
\end{abstract}

C 2018 by the authors; licensee Growing Science, Canada.

\section{Introduction}

Construction industry is considered as the backbone of any country economic growth and development. According to Meyer et al. (2017), "development strategies should be formulated to achieve sustainable inclusive economic growth and economic development". Hence, it is essential to understand the dynamics of construction industry because of its significance to the economic growth and development. The industry is contributing in terms of employment and providing billions of job opportunities in developed and developing countries. Since Pakistan is recognised as a developing country, the construction industry has a compact growth and contributing on economy of the country (Khan \& Gul, 2017). However, a huge amount of investment is coming to Pakistan in construction industry such as \$43USD billion in two islands of town Bin Qasim, \$68USD billion for a new city project in Hawksbay, Karachi, \$60USD billion of China Pakistan economic corridor project (CPEC) (Asia, 2018; Gazder \& Khan, 2018). Furthermore, naya Pakistan housing scheme will begin and there will be five million more houses across the country (Wasim, 2018).

The country is presently experiencing a rapid development in construction industry. Due to dynamic nature of construction industry the construction projects are more involved in uncertainties and risks

\footnotetext{
* Corresponding author

E-mail address: imran.imranb2001@gmail.com (M. Imran)

(C) 2019 by the authors; licensee Growing Science, Canada. doi: $10.5267 /$ j.dsl.2018.12.002
} 
(Wu et al., 2017). This is very important for organisations and government to plan for project risks, which is very critical for the project success (Khan \& Gul, 2017). The investigation of risk is crucial element of project management to achieve the project success (Aloini et al., 2007). The risk is measured in terms of the consequences and probability of not achieving the set of project goals (Jaafari, 2001). Besides, in construction project, the risk cannot be eliminated, but it can be controlled and minimized. The project risk is an uncertain event, which may have positive or negative effect on the success of the projects. There are many uncertain events or sources in construction projects including resources risk, financial risk, legal \& regulations risk, construction risk, natural risk, design risk, technical risk, labour risk (Khan \& Gul, 2017; Wu et al., 2017).

Moreover, the construction industry has a deficiency to identify the risk compared with other industries such as finance. However, many project suffers poor identification of risk assessment. However, the risk factors affecting project success should be investigated in depth. The main objective of the study is to investigate the risk factors affecting construction project success in the context of Pakistan whereas many construction projects are underworking.

\section{Literature Review}

This section discusses the past studies published on project success and risk factors. Furthermore, it examines different hypotheses between risk factors and project success.

\subsection{Project Success}

There are many authors defined the project success conceptually and operationally such as Pinto and Pinto (1991) who stated that project success covers the cost, time, quality and customer satisfaction. In other study, project success was defined as the success involved in project efficiency, impact on clients, staff, business, environment and preparation for future (Carvalho \& Rabechini, 2017). In more recent studies, project success is explained in terms of quality, cost, time, health \& safety, environmental control, satisfaction of participants, users and commercial values (Wu et al., 2017).

However, the success of a project success is influenced by many factors, such as the effect of contractual flexibility on project success (Wu et al., 2018). Some people named the corporate reputation, work bulling, team learning, innovation, emotional intelligence, job satisfaction, entrepreneurial orientation and human resource practices as important factors for the success of the project (Creasy \& Carnes, 2017; Irfan \& Hassan, 2017; Martens et al., 2018; Rezvani et al., 2016; Yang et al., 2015). More specifically, the main concern of the current study is to investigate the effect of risk factors on project success, in this regard, some studies identified and investigated different risk factors such as technological risk, human risk, usability risk, project team risk, project risk, organisational risk and strategic risk (Paré et al., 2008). Moreover, there are various views on project success and different authors investigated various factors to recognise the project success. The current study combines the risk management with project management, the combination of risk management and project success are more closely related. Similarly, we identify the risk factors and their impacts on project success in terms of cost, time, quality, safety and environmental sustainability.

\subsection{Risk Factors and Project Success}

The risk is a problem which has not yet happen but it could cause some loss or threat for project success (Kerzner \& Kerzner, 2017). Furthermore, risk is an event to know as a probability, whereas uncertainty is a situation in terms of a numerical probability, characterised by a conscious lack of knowledge about the results of an event, which cannot be specified (Perminova et al., 2008). However, various studies investigated the risk factors in construction industry project and identified their importance and classified the risk factors. More specifically, risk involves in gain and loss of an organization, in this respect, identification of risk would be the involvement of project success. The risk factors is exposed during the implementation of the projects where organisations can prevent the damage of an investment. Moreover, Chandra (2015) identified six risk factors in construction industry project success such as 
natural risk, design risk, resources risk, financial risk, legal \& regulation risk and construction risk. In other study, Khan and Gul (2017) discussed the impact of five risk factors on construction project success such as design risk, financial risk, technical risk, labour risk and external risk.

Furthermore, Zwikael and Ahn (2011) conducted a study in three countries such as Japan, new Zealand and Israel, and found that all three countries considered the risk management as important element for project success. However, the current study considers the risk factors such as design risk, financial risk, technical risk, labour risk and external risk. They expected that the proposed risk factors might be the major risk factors for project success in Pakistan as well and investigated their impacts on construction project success in Pakistan. Moreover, Fig. 1 presents the risk cycle in the construction industry. Therefore, the current study considers the contribution in term of risk management.

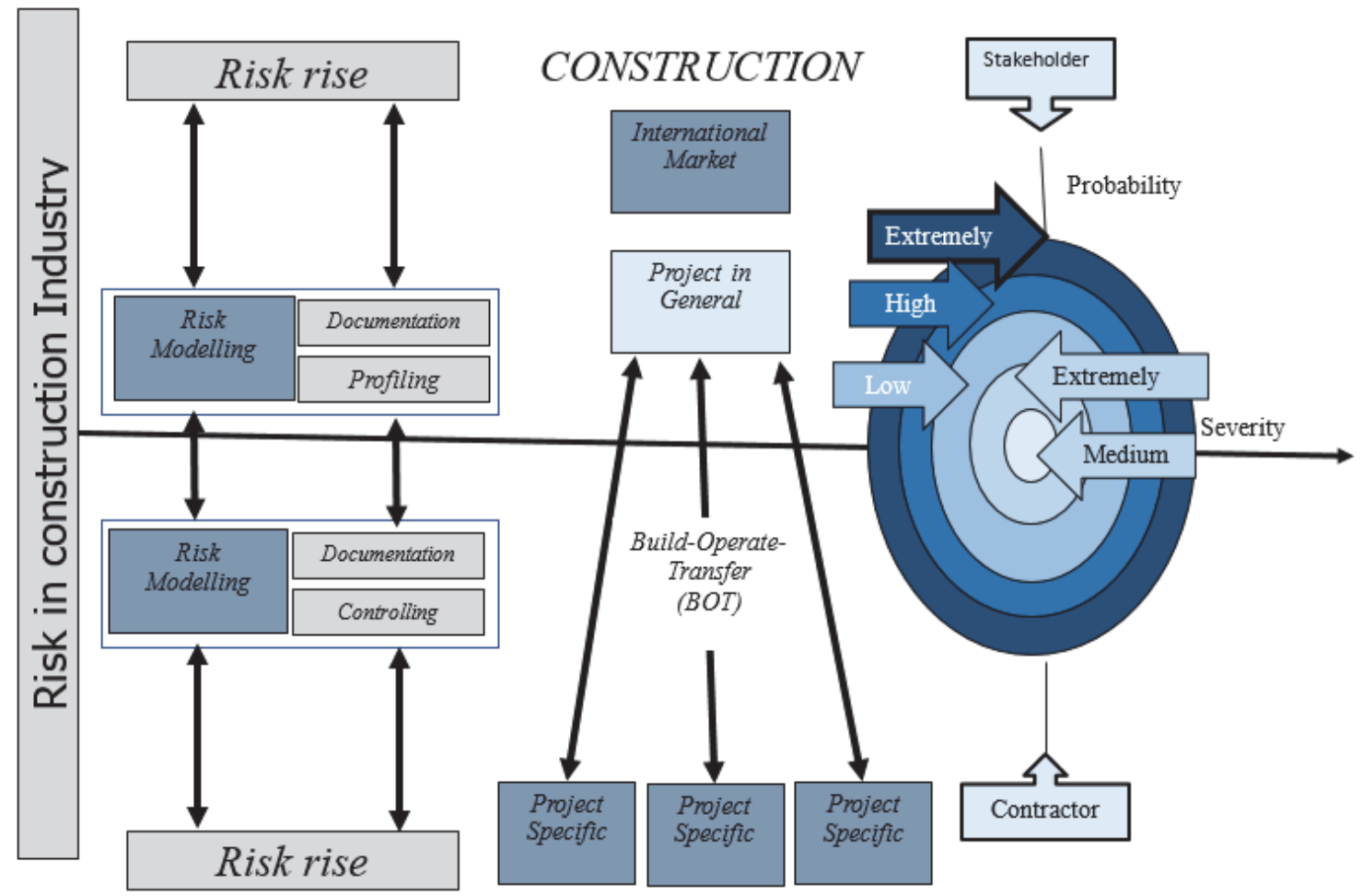

Fig. 1. Risk cycle (Iqbal et al., 2015)

\subsection{Design Risk and Project Success}

As discussed in the last section, there are many uncertain risk factors affecting the project success. However, some studies considered the design risk factor for the success of construction project. According to Almasi et al. (2011) design changes are the major risk for construction project. Besides, the design team experience can also affect the project success (Buvik \& Rolfsen, 2015). In addition, incomplete drawings, inaccurate design, innovation of design, frequent changes in design, incomplete specifications have considerable effects on project success (Al-Ageeli \& Alzobaee, 2016). Therefore, the consideration of design risk for project success is very important, thus, the current study proposes the following hypothesis to validate the relationship between design risk and project success in Pakistan.

H1: Design risk has a positive effect on the success of the project.

\subsection{Financial Risk and Project Success}

Financial risk is related with company capital, investment and company loans (Sapienza et al., 2009). Xenidis and Angelides (2005) stated that currency exchange, cost of capital, inflation rate are 
considered as the major financial risk which overrun the project cost. In other study heavy loans of the company was stated to reduce the company profitability (Aladăg \& Işik, 2017). Additionally, cost overrun was the cause of financial loss, due to this loss, clients and contractors can suffer, significantly (Patah \& de Carvalho, 2007). Therefore, the consideration of financial risk is very important for any construction project. Hence, the present study proposes the following hypothesis.

H2: Financial risk has a positive effect on the success of the project.

\subsection{Technical risk and project success}

Technical risk is explained as errors in estimation and incorrect calculations (Vaughan, 1997). The technical problem, complex design, insufficient experience of new technology and utilizing new technologies are major reasons of technical rick for any construction project (Gann \& Salter, 2000). According to Perrow (2011) most contractors face with technology risk due to ambiguity with lack of experience needed in the installation of advance technologies. Additionally, it is not guaranteed that the use of new technology can increase the efficiency of the projects. However, empirical investigation of technology risk is very important to judge the project success. Hence, the current study proposes the following hypothesis,

H3: Technical risk has a positive effect on the project success.

\subsection{Labour risk and project success}

Labour risk is associated with poor management ability, poor competency of labour, inability of professional and mangers, lack of safety insurance of employee and inability of skilled labour (Wu et al., 2017). Rezakhani (2012) presented that firm should control the labour risk to avail the professional and skilled labour and also maintain the employee safety as well and these steps can help for the success of projects. However, the proper uses of skilled labour is very important for project success, hence the present study proposes the following hypothesis to test the empirical effect of labour risk on construction project success.

H4: Labour risk has a positive effect on the project success in construction industry.

\subsection{External risk and project success}

External risk is explained as the risk due to government such as bureaucratic regulations, excessive procedure of government due to other external risks, such as inflation in construction material and equipment. These kinds of risks cannot be handled by project manager; however, firms can assess the external risks for making better decisions towards project success. Furthermore, external risks are divided into political and socio-cultural risks (Jarkas \& Haupt, 2015). Besides, some researchers identified external risks as environmental factors such as hazards, earth quick, humidity, noise and poor temperature. However, the consideration of external risk is very important for project success, hence the study investigates external risk impacting on project success. Therefore, the following hypothesis is proposed:

H5: External risks have positive effects on the project success.

\section{Methods}

The present study considers the population from the Pakistan engineering council (PEC) website and 73 construction companies were identified (PEC, 2018). Moreover, the study uses the Yamane (1973) sample size formula and finalised 61 firms for data collection. The simple random sample technique has taken to distribute the questionnaire among the firms. In this regard, simple random selection of respondents was made using the Microsoft Excel 2016 (RAND) function using the technique by Imran et al. (2018). The scale of the study has been adapted from the study of Altoryman (2014). The scale of design risk consists of 9 items, financial risk consists of 4 items, technical risk consists of 8 items, 
labour risk consists of 6 items and external risk consists of 5 items. The dependent variable scale was adapted from the study of Carvalho and Rabechini Junior (2015) with 7 items.

The structural equation modelling techniques has been employed for data analysis. The latest version of smartPLS 2.3.8 was employed to run the SEM analysis. PLS-SEM data analysis was divided into two steps including measurement model and structural model.

\section{Results Findings and Discussion}

\subsection{Measurement Model}

Five criteria were used to validate the measurement model such as Cronbach alpha $(\alpha)$, composite reliability (CR), average variance extracted (AVE), Fornell \& Larcker criterion and HeterotraitMonotrait ratio of correlations (HTMT). In terms of data reliability, the values of construct should be more than 0.70 for Cronbach alpha and composite reliability and equal or more than 0.50 for AVE (Hair Jr et al., 2016). However, the result of construct internal reliability was achieved. All values were observed within threshold values and the results can be seen in Table 1. In respect to construct validity, the present study used two criteria such as fornell-larcker criterion and Heterotrait-Monotrait ratio of correlations (HTMT). The fornell-larcker criterion compares the square root of the AVE with the correlation of latent constructs. A latent construct should explain better the variance of its own indicator rather than the variance of other latent constructs.

\section{Table 1}

Constructs reliability values

\begin{tabular}{llll}
\hline Constructs & Cronbach's Alpha & Composite Reliability & Average Variance Extracted (AVE) \\
\hline Design Risk & 0.784 & 0.852 & 0.537 \\
External Risk & 0.824 & 0.876 & 0.587 \\
Financial Risk & 0.887 & 0.93 & 0.815 \\
Labour Risk & 0.832 & 0.876 & 0.544 \\
Project Success & 0.838 & 0.879 & 0.51 \\
Technical Risk & 0.880 & 0.904 & 0.541 \\
\hline
\end{tabular}

Table 2

Fornell-Larcker criterion

\begin{tabular}{lllllll}
\hline Constructs & Design Risk & External Risk & Financial Risk & Labour Risk & Project Success & Technical Risk \\
\hline Design Risk & 0.733 & & & & & \\
External Risk & 0.427 & 0.766 & & & & \\
Financial Risk & -0.144 & -0.24 & 0.903 & & & \\
Labour Risk & 0.348 & 0.768 & -0.257 & 0.737 & & \\
Project Success & 0.707 & 0.404 & -0.238 & 0.418 & 0.714 & 0.736 \\
Technical Risk & 0.276 & 0.599 & -0.359 & 0.785 & 0.371 & \\
\hline
\end{tabular}

Table 3

HTMT (Constructs validity values)

\begin{tabular}{|c|c|c|c|c|c|c|}
\hline Constructs & Design Risk & External Risk & Financial Risk & Labour Risk & Project Success & Technical Risk \\
\hline \multicolumn{7}{|l|}{ Design Risk } \\
\hline External Risk & 0.498 & & & & & \\
\hline Financial Risk & 0.177 & 0.293 & & & & \\
\hline Labour Risk & 0.456 & 0.89 & 0.306 & & & \\
\hline Project Success & 0.843 & 0.479 & 0.292 & 0.491 & & \\
\hline Technical Risk & 0.346 & 0.685 & 0.399 & 0.912 & 0.399 & \\
\hline
\end{tabular}

Therefore, the square root of each construct's AVE should have a greater value than the correlations with other latent constructs. Thus, the current study found the accepted result of fornell-larcker criterion 
and the results can be seen in Table 2 . The other criteria for construct validity is a HTMT, the values of all constructs should be less than 1.0 (Hair Jr et al., 2016). However, the present study constructs all values were lying below 1, hence the construct validity is validated. The result can be seen in Table 3 .

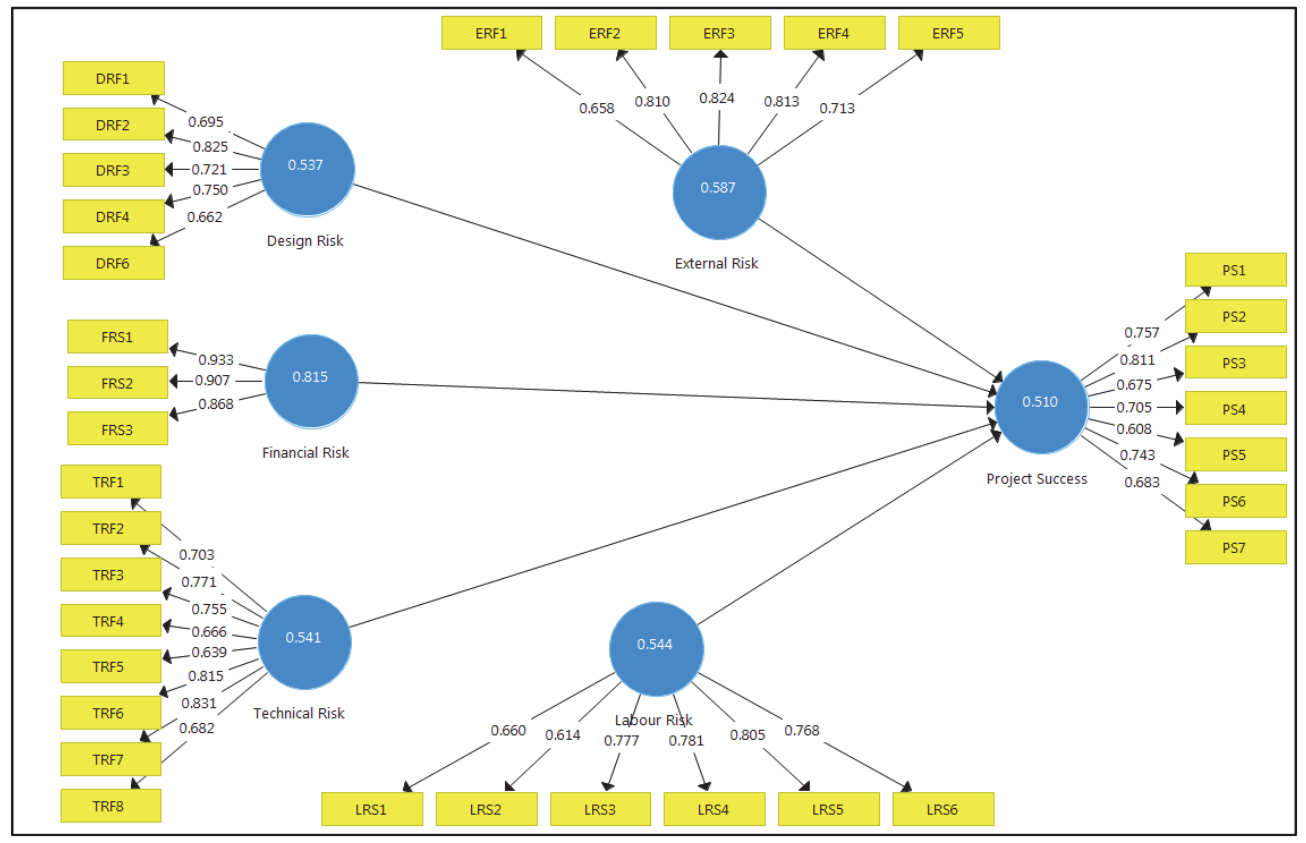

Fig. 2. Framework

\subsection{Structural Model}

The structural model validates the three criteria's as well, for the hypotheses decision we have used the path coefficient criteria, for model assessment, the current study has used the coefficient of determination $\left(\mathrm{R}^{2}\right)$, effect size $\left(\mathrm{f}^{2}\right)$ and predictive relevance $\left(Q^{2}\right)$. In path coefficient the hypothesis is accepted if the $\mathrm{t}$-values is more than 1.96 at 0.05 significance level. In terms of $\mathrm{R}^{2}$ acceptable with 0.75 , 0.50 , and 0.25 are described as substantial, moderate and weak respectively (Hair Jr et al., 2016). The effect size (f2) is considered $0.02,0.15$, and 0.35 for the significant independent variables represent weak, moderate and substantial effects, respectively (Hair Jr et al., 2016). The results can be seen in Table 4 and Table 5.

\section{Table 4}

Direct relationship results

\begin{tabular}{llllll}
\hline Hypothesis & $\beta$ & Standard Deviation & T Values & P Values & Decision \\
\hline H1: Design Risk $\rightarrow$ Project Success & 0.644 & 0.087 & 7.409 & 0.000 & Accept \\
H2: Financial Risk $\rightarrow$ Project Success & 0.345 & 0.070 & 2.947 & 0.003 & Accept \\
H3: Technical Risk $\rightarrow$ Project Success & 0.126 & 0.065 & 3.396 & 0.000 & Accept \\
H4: Labour Risk $\rightarrow$ Project Success & 0.801 & 0.080 & 6.721 & 0.000 & Accept \\
H5: External Risk $\rightarrow$ Project Success & 0.058 & 0.146 & 0.395 & 0.693 & Reject \\
\hline
\end{tabular}

\section{Table 5}

Values of coefficient of determination (R2) and effect size (f2)

\begin{tabular}{lll}
\hline Constructs & $f^{2}$ & $R^{2}$ \\
\cline { 2 - 3 } & Project Success & Project Success \\
\hline Design Risk & 0.508 & 0.547 \\
Financial Risk & 0.152 & \\
Technical risk & 0.315 & \\
Labour Risk & 0.462 & \\
External Risk & 0.003 & \\
\hline
\end{tabular}


Q-square criteria is used to predict the model relevance. The Q-square value should be above zero, values more than zero indicate that the values of the constructs are well reconstructed, and the model has predictive relevance (Hair Jr et al., 2016). The present study has found the model predictive relevance. The results of Q-square can be seen in Table 6.

\section{Table 6}

Predictive relevance

\begin{tabular}{llll}
\hline Constructs & SSO & SSE & $\mathrm{Q}^{2}(=1-\mathrm{SSE} / \mathrm{SSO})$ \\
\hline Design Risk & 305 & 305 & \\
External Risk & 305 & 305 & 0.23 \\
Financial Risk & 183 & 183 & \\
Labour Risk & 366 & 366 & \\
Project Success & 427 & 328.972 & \\
Technical Risk & 488 & 488 & \\
\hline
\end{tabular}

The current study investigated the effects of risk factors on the success of the construction project. The current study found the positive impact of design risk, financial risk, technical risk and labour risk on project success, hence the hypotheses H1 to H4 are accepted. Considering H1, the t-value of 7.409 is greater than $1.96(7.409>1.96)$, which indicates that design risk had a positive effect on the success of project. Additionally, the p-value is 0.000 , reflecting the impact is statistically significant. Therefore, we do not reject the hypothesis 1. This finding is aligned with the work of Khan and Gul (2017). Furthermore, the $\beta=0.644$, indicates that the design risk (predictor) cause 0.644 variation in the project success due to single unit deviation from standard.

Considering the financial risk impact on the success of project, it is evident that t-value is 2.947 (2.9.7 $>1.96$ ), indicating that we fail to reject the null hypothesis 2 . Moreover, the p-value confirmed that the impact is statistically significant $(=0.003<0.05)$. Therefore, this study supports the previous work of Chandra (2015). Additionally, $\beta$ value scored 0.354 , indicating that the predictor (financial risk) causes variation in the project success by this margin when there is single unit deviation in the standard.

In addition to that, in regard to technical risk, it has had a positive impact on the success of project, since findings have revealed that $\mathrm{t}$-value is 3.396, which is greater than threshold value $(3.396>1.96)$. The p-value is evident to have statistical and significant impact $(=0.000<0.05)$. Therefore, we fail to reject the hypothesis 3. These results are consistent with previous researchers' results (Chandra, 2015; Khan \& Gul, 2017). Considering the $\beta$ value, it is evident that the predictor (technical risk) causes variation of 0.126 on the success of project in case of single unit deviation from standard.

Labour risk in relation to the success of project was evaluated. The results show that t-value is 6.721 , which is greater than 1.96 (i.e. $6.721>1.96$ ), indicating that there was no strong evidence against null hypothesis 4 . In other words, we do not reject null hypothesis. In addition to that, the impact is significant when the level of significance is five percent. Therefore, this study supports the work of Chandra (2015) and Khan and Gul (2017) in this regard. The $\beta$ value reflects 0.801 , which is causing variation in the success of project when there is a single unit deviation from the standard. This is the predictor that causes the most variation.

Lastly, the external risk associated with the success of project was examined and the results have revealed that t-value is 0.395 , which is less than the threshold value of $1.96(0.395<1.96)$. Hence, there is statistically strong significant evidence against hypothesis 5 and therefore, we reject it. Interestingly, this predictor causes a low variation as evident $\beta=0.058$, which is the lowest among all obtained values. As a result, this means that external risk has no impact on the project success. In other words, the study found no relationship between external risk and project success. The findings contradict the earlier work of Chandra (2015) and Khan and Gul (2017). It can be also said that this risk factor is not important for the construction firms during decision making towards project implementation. 


\section{Conclusion and recommendations}

Construction industry of Pakistan plays an important role for the economic growth and development. It has been expanding in recent years and the job opportunities are generating at a constant rate. With the change in government, a slogan of "Naya Pakistan" (New Pakistan) has led to the development of "Naya Pakistan Housing Scheme". In this regard, this study has evaluated the dynamics of construction industry in Pakistan for this scheme and such other schemes emerging in last one-and-a-half year. By evaluating the literature, most common types of risks associated with the project success were examined in this research.

Results have confirmed that design risk, financial risk, technical risk and labour risk had positive effects on the success of project. These factors play a vital role on the construction industry and positively affect the outcomes of the projects. Additionally, these are evident to be linked in statistically significant manner with the project success in the dynamics of Pakistan's construction business. However, the external risk is not statistically associated with the project success. Moreover, the study has confirmed that the size effects of design risk $\left(f^{2}=0.508\right)$, labour risk $\left(f^{2}=0.462\right)$, technical risk $\left(f^{2}=0.315\right)$ and financial risk $\left(f^{2}=0.152\right)$ were strong while external risk $\left(f^{2}=0.003\right)$ was small. Additionally, the variance $\left(R^{2}=0.547\right)$ was moderate as this reflects that $54.7 \%$ variation in project success could be expected to be caused by the independent variables (predictors). Moreover, the Qsquare results have shown that the model of the study had predictive relevance as well. Hence, in Pakistan, the construction industry has found to lead to a project success positively affected by technical, financial, labour and design risks but these risks vary in their impacts whereas external risks were not associated with the project success.

In the light of findings at hand, it is recommended that the construction firms consider the design risk, financial risk, technical risk and labour risk factors for proper implementation of project for project success. The government of Pakistan and construction firms of the country should work in collaboration with the environmental scanning and there should be the adoption of more sophisticated decisionmaking tools for the construction business in order to evaluate the risk factors for project management. Future studies should validate the current study research framework in other industries such as manufacturing, agriculture, etc. Additionally, the present study has adopted the cross-sectional approach, thus, the future studies should adopt the longitudinal approach to validate the present results. Moreover, future studies should also consider other risk factors such as ineffective communication, insufficient internal expertise, lack of proper management structure, lack of integration into the future studies research framework.

\section{References}

Al-Ageeli, H. K., \& Alzobaee, A. S. J. A. (2016). The Most Influential Factor on the Stumble and Failure of the governmental Projects. Journal of Engineering, 22(2), 93-110.

Aladağ, H., \& Işik, Z. (2017). Role of Financial Risks in BOT Megatransportation Projects in Developing Countries. Journal of Management in Engineering, 33(4), 04017007.

Almasi, G., Moradianmina, R., \& Zavari, S. (2011). Changes and their main causes and effects in Iranian projects. Paper presented at the Management and Service Science (MASS), 2011 International Conference on.

Aloini, D., Dulmin, R., \& Mininno, V. (2007). Risk management in ERP project introduction: Review of the literature. Information \& Management, 44(6), 547-567.

Altoryman, A. (2014). Identification and assessment of risk factors affecting construction projects in the Gulf region: Kuwait and Bahrain. The University of Manchester (United Kingdom).

Asia, B. (2018). CONSTRUCTION INDUSTRY. Retrieved from https://www.buildasia.net/page.php?id=143

Buvik, M. P., \& Rolfsen, M. (2015). Prior ties and trust development in project teams-A case study from the construction industry. International Journal of Project Management, 33(7), 1484-1494. 
Carvalho, M. M., \& Rabechini, R. (2017). Can project sustainability management impact project success? An empirical study applying a contingent approach. International Journal of Project Management, 35(6), 1120-1132.

Carvalho, M. M. d., \& Rabechini Junior, R. (2015). Impact of risk management on project performance: the importance of soft skills. International Journal of Production Research, 53(2), 321-340.

Chandra, H. P. (2015). Structural equation model for investigating risk factors affecting project success in Surabaya. Procedia Engineering, 125, 53-59.

Creasy, T., \& Carnes, A. (2017). The effects of workplace bullying on team learning, innovation and project success as mediated through virtual and traditional team dynamics. International Journal of Project Management, 35(6), 964-977.

Gann, D. M., \& Salter, A. J. (2000). Innovation in project-based, service-enhanced firms: the construction of complex products and systems. Research policy, 29(7-8), 955-972.

Gazder, U., \& Khan, R. A. (2018). Effect of Organizational Structures and Types of Construction on Perceptions of Factors Contributing to Project Failure in Pakistan. Mehran University Research Journal of Engineering and Technology, 37(1), 12.

Hair Jr, J. F., Hult, G. T. M., Ringle, C., \& Sarstedt, M. (2016). A primer on partial least squares structural equation modeling (PLS-SEM): Sage Publications.

Imran, M., Jian, Z., Haque, A.U., Urbański, M., and Nair, S.L.S. (2018). Determinants of Firm's Export Performance in China's Automobile Industry, Sustainability, 10(11), 1-23. 4078; https://doi.org/10.3390/su10114078

Irfan, M., \& Hassan, M. (2017). The effect of project success on corporate reputation of the public sector organizations in Pakistan. Int. J. Econ. Manag, 11, 815-832.

Iqbal, S., Choudhry, R. M., Holschemacher, K., Ali, A., \& Tamošaitienè, J. (2015). Risk management in construction projects. Technological and Economic Development of Economy, 21(1), 65-78.

Jaafari, A. (2001). Management of risks, uncertainties and opportunities on projects: time for a fundamental shift. International Journal of Project Management, 19(2), 89-101.

Jarkas, A. M., \& Haupt, T. C. (2015). Major construction risk factors considered by general contractors in Qatar. Journal of Engineering, Design and Technology, 13(1), 165-194.

Kerzner, H., \& Kerzner, H. R. (2017). Project management: a systems approach to planning, scheduling, and controlling: John Wiley \& Sons.

Khan, R. A., \& Gul, W. (2017). Emperical study of critical risk factors causing delays in construction projects. Paper presented at the Intelligent Data Acquisition and Advanced Computing Systems: Technology and Applications (IDAACS), 2017 9th IEEE International Conference on.

Martens, C. D. P., Machado, F. J., Martens, M. L., \& de Freitas, H. M. R. (2018). Linking entrepreneurial orientation to project success. International Journal of Project Management, 36(2), 255-266.

Meyer, D., Masehla, T. M., and Kot, S. (2017). The relationship between economic growth and economic development: A regional assessment in South Africa, Journal of Advanced Research in Law and Economics, 8(4), 1377-1387.

Paré, G., Sicotte, C., Jaana, M., \& Girouard, D. (2008). Prioritizing the risk factors influencing the success of clinical information system projects. Methods of information in medicine, 47(03), 251259.

Patah, L. A., \& de Carvalho, M. M. (2007). Measuring the value of project management. Paper presented at the Management of Engineering and Technology, Portland International Center for.

PEC. (2018). LIST OF CONSTRUCTOR/OPERATOR FIRMS. Retrieved from http://verification.pec.org.pk/COFirmList

Perminova, O., Gustafsson, M., \& Wikström, K. (2008). Defining uncertainty in projects-a new perspective. International Journal of Project Management, 26(1), 73-79.

Perrow, C. (2011). Normal Accidents: Living with High Risk Technologies-Updated Edition: Princeton university press.

Pinto, M. B., \& Pinto, J. K. (1991). Determinants of cross-functional cooperation in the project implementation process. 
Rezakhani, P. (2012). Classifying key risk factors in construction projects. Buletinul Institutului Politehnic din lasi. Sectia Constructii, Arhitectura, 58(2), 27.

Rezvani, A., Chang, A., Wiewiora, A., Ashkanasy, N. M., Jordan, P. J., \& Zolin, R. (2016). Manager emotional intelligence and project success: The mediating role of job satisfaction and trust. International Journal of Project Management, 34(7), 1112-1122.

Sapienza, P., Zingales, L., \& Maestripieri, D. (2009). Gender differences in financial risk aversion and career choices are affected by testosterone. Proceedings of the National Academy of Sciences, pnas. 0907352106.

Vaughan, D. (1997). The Challenger launch decision: Risky technology, culture, and deviance at NASA: University of Chicago Press.

Wasim, A. (2018). PM Khan to personally monitor govt's 5 million housing scheme. Dawn. Retrieved from https://www.dawn.com/news/1432094

Wu, G., Liu, C., Zhao, X., \& Zuo, J. (2017). Investigating the relationship between communicationconflict interaction and project success among construction project teams. International Journal of Project Management, 35(8), 1466-1482.

Wu, G., Zhao, X., Zuo, J., \& Zillante, G. (2018). Effects of contractual flexibility on conflict and project success in megaprojects. International Journal of Conflict Management, 29(2), 253-278.

Wu, Z., Nisar, T., Kapletia, D., \& Prabhakar, G. (2017). Risk factors for project success in the Chinese construction industry. Journal of Manufacturing Technology Management, 28(7), 850-866.

Xenidis, Y., \& Angelides, D. (2005). The financial risks in build-operate-transfer projects. Construction Management and Economics, 23(4), 431-441.

Yamane, T. (1973). Statistics: An introductory analysis.

Yang, L.-R., Chen, J.-H., Wu, K.-S., Huang, D.-M., \& Cheng, C.-H. (2015). A framework for evaluating relationship among HRM practices, project success and organizational benefit. Quality \& Quantity, 49(3), 1039-1061.

Zwikael, O., \& Ahn, M. (2011). The effectiveness of risk management: an analysis of project risk planning across industries and countries. Risk Analysis: An International Journal, 31(1), 25-37.

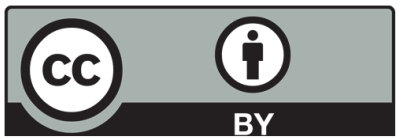

(C) 2019 by the authors; licensee Growing Science, Canada. This is an open access article distributed under the terms and conditions of the Creative Commons Attribution (CC-BY)

license (http://creativecommons.org/licenses/by/4.0/). 